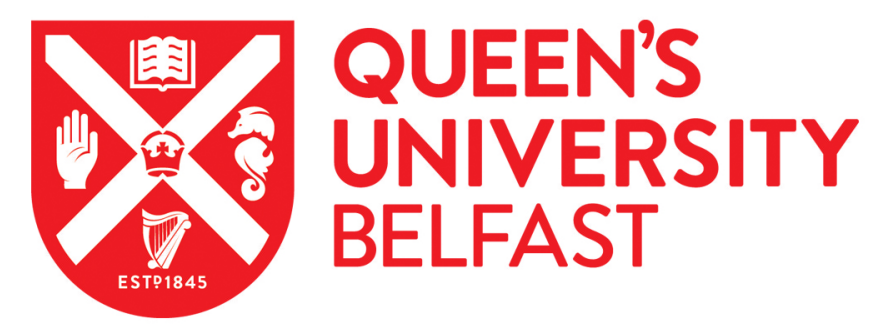

\title{
"No Artist has Ethical Sympathies": Oscar Wilde, Aesthetics, and Moral Evolution
}

Sumpter, C. (2016). "No Artist has Ethical Sympathies": Oscar Wilde, Aesthetics, and Moral Evolution. Victorian Literature and Culture, 44(3), 623-40. https://doi.org/10.1017/S1060150316000127

\author{
Published in: \\ Victorian Literature and Culture
}

Document Version:

Peer reviewed version

Queen's University Belfast - Research Portal:

Link to publication record in Queen's University Belfast Research Portal

\section{Publisher rights}

(C) 2016 Cambridge University Press

This article has been published in a revised form in Victorian Literature and Culture http://dx.doi.org/10.1017/S1060150316000127 This version is free to view and download for private research and study only. Not for re-distribution, re-sale or use in derivative works.

\section{General rights}

Copyright for the publications made accessible via the Queen's University Belfast Research Portal is retained by the author(s) and / or other copyright owners and it is a condition of accessing these publications that users recognise and abide by the legal requirements associated with these rights.

Take down policy

The Research Portal is Queen's institutional repository that provides access to Queen's research output. Every effort has been made to ensure that content in the Research Portal does not infringe any person's rights, or applicable UK laws. If you discover content in the Research Portal that you believe breaches copyright or violates any law, please contact openaccess@qub.ac.uk. 
“No Artist has Ethical Sympathies”: Oscar Wilde, Aesthetics, and Moral Evolution

\section{By Caroline Sumpter}

"There is no mode of action, no form of emotion, that we do not share with the lower animals” (137). This evolutionary claim is not attributable to Darwin, but to Oscar Wilde, who allows Gilbert to voice this bold assertion in "The True Function of Criticism”. While critics have long wrestled with the ethical stance and coherence of Wilde's writings, they have overlooked a significant influence on his work: debates concerning the evolution of morality that animated the periodicals in which he was writing. Wilde was fascinated by the proposition that complex human behaviours, including moral and aesthetic responses, might be traced back to evolutionary impulses. Significantly, he also wrote for a readership already engaged with these controversies.

Here, I argue that Wilde’s writings on morality, sympathy and aesthetics were shaped by those wider periodical debates over evolutionary science. Wilde's protests against the assumed links between morality, nature and art in “The Decay of Lying” (1889) and "The True Function and Value of Criticism” (1890) - both published in the Nineteenth Century create new meanings in the context of a periodical that also showcased Herbert Spencer and T. H. Huxley's writings on evolution and ethics. ${ }^{1}$ Writing on Wilde’s “The Soul of Man under Socialism” (1891), first published in the Fortnightly Review, Josephine Guy is right to argue that its "relationship with contemporary periodical literature, and thus to what is local and topical, has been marginalized” (“'Soul of Man’” 66-67), and her own work begins to redress this balance. ${ }^{2}$ Yet, as we will see, it is not just Wilde's engagement with debates over socialism, but his wider writings on aesthetics, sympathy and morality that also deserve to be read in this "local and topical” context. 
As editors of Wilde’s notebooks, Philip E. Smith and Michael S. Helfand have done meticulous and important work in tracing the sources of his early reading, including scientific influences. However, Wilde's position was not static, and his participation in later journalistic evolutionary debates has led me to depart from some of their key assertions. These include the claim that Wilde's critical position was fully established by the late 1870s, the assumption that Wilde adopted Spencer's “conclusions” about society (29), and the assertion that Wilde took an "antimaterialist [...] position in culture and politics" (14). Instead, I argue that the Nineteenth Century and Fortnightly Review reveal a more materialist Wilde, participating in debates over the biological origins of morality, and indebted to socialist understandings of moral impulses as feelings that evolve alongside changing economic relations.

In examining Wilde’s engagement with evolutionary debates in the Nineteenth

Century, I pursue a series of interlinked arguments. Firstly, I foreground connections between Huxley's conception of the role of art in a non-moral universe and Wilde's own aesthetic credo. Secondly, I consider Spencer's attempts to link the evolution of art and sympathy, and explore the significance of his periodical writings on morality and altruism. Finally, I relate Wilde's understanding of sympathy to his interest in tribal ethics, revealing his fusion of biological and socialist models of moral evolution. The Nineteenth Century can be seen as a forgotten link between Wilde’s interest in biological science and his writings on creativity and art - a link that offers fresh insights into his aesthetic position. Throughout, I reveal the evolutionary progressivism that underlies Wilde’s writings on ethics and art.

\section{'Thrown into the bargain of life': Evolution and the Art Instinct}

Embarking on his critical essays, Wilde wrote with the speed of the jobbing journalist. By publishing his major pieces in the Nineteenth Century and the Fortnightly Review, liberal monthlies committed to open discussion of science, ethics and religion, Wilde was conscious 
of entering a wider public debate. ${ }^{3}$ He clearly read and responded to other periodical contributions: as Guy has noted, Wilde incorporated references to recent Nineteenth Century debates on the Church into the proofs of the "Soul of Man". ${ }^{4}$ Wilde was a professed admirer of both the Nineteenth Century and the Fortnightly: it seems unlikely that he would have overlooked Huxley’s prominent contributions to both, given his close engagement with Huxley’s writings in his university notebooks (Oxford Notebooks 49-55, 57-61, 214).

Huxley’s appeal to Wilde is unsurprising: in an article published in the Nineteenth Century in 1900, Leslie Stephen cited Huxley’s claim that science and literature "are not two things, but two sides of one thing”, a phrase, he claimed, which "indicates the quality which makes Huxley’s writings as refreshing to the literary as to the scientific critic” (907). “Huxley’s best essays deserve to be put on a level with the finest examples of Swift or other great literary athletes”, Stephen asserted. Here, I suggest that Huxley’s contributions to the Nineteenth Century could indeed lay claim to being some of his best essays in Stephen's terms, and that they also help to illuminate some of Wilde's most celebrated critical pieces. An important essay is Huxley’s “The Struggle for Existence: A Programme”, which was published in the Nineteenth Century in February 1888, less than a year before "The Decay of Lying” appeared. If Huxley’s article explored the human implications of a non-moral nature, Wilde’s essay reveals intriguing parallels, and builds on Huxley's brief reflections on the place of art and the artist's role. ${ }^{5}$

In his early unpublished article “[The Rise of] Historical Criticism” (1879), Wilde had presented a view of nature that appears ordered and harmonious: Aristotle, he suggested, was the first to point out "that nature, including the development of man is not full of incoherent episodes like a bad tragedy. That inconsistency and anomaly are as impossible in the moral as they are in the physical world" (Complete Works IV: 32). Ten years later, in the "Decay of Lying”, however, Vivian muses on the fact that nature is utterly "indifferent” to humanity: 
"Whenever I am walking in the park here, I always feel I am no more to nature than the cattle that browse on the slope, or the burdock that blooms in the ditch. Nothing is clearer than that nature hates Mind” (36). The symmetry between nature and human morality can no longer be maintained. Indeed, in “The True Function”, humanity indeed seems to be trapped in a bad tragedy, where no justice or moral consistency can be assumed. "Life is terribly deficient in form”, Gilbert muses. "Its catastrophes happen in the wrong way, and to the wrong people" (437).

In "The Struggle for Existence”, Huxley rehearsed arguments that would become better known through his celebrated Romanes Lecture "Evolution and Ethics” (1893). While from a purely intellectual perspective nature appears "the incarnation of a faultless logical process", if our "moral sympathies" are engaged it is something very different: indeed, "from the point of view of the moralist the animal world is on about the same level as a gladiator's show" ("Struggle” 163). Huxley was, however, careful to argue for the special status of both art and society. Although society, like art, is part of nature, Huxley claimed that it is:

Convenient to distinguish those parts of nature in which man plays the part of immediate cause, as some thing apart; and, therefore, society, like art, is usefully to be considered as distinct from nature. It is the more desirable, and even necessary, to make this distinction, since society differs from nature in having a definite moral object; whence it comes about that the course shaped by the ethical man - the member of society or citizen - necessarily runs counter to that which the non-ethical man - the primitive savage, or man as a mere member of the animal kingdom - tends to adopt. The latter fights out the struggle for existence to the bitter end, like any other animal; the former devotes his best energies to the object of setting limits to the struggle. (“Struggle” 165) 
Ethical man should, Huxley asserted, strive to rise above his animal instincts - his "ape and tiger” promptings, as he later described them with a nod to Tennyson (Evolution and Ethics 63). Despite its offence to human "moral sympathies", Huxley was careful to assert in "The Struggle for Existence” that nature was non-moral, not immoral, and that the conception of an evil nature was as erroneous as the conviction of its benevolence. Significantly, it was to art which Huxley turned to counter a Schopenhaurian pessimism, for there was a "sufficiently obvious fact” which:

renders the hypothesis that the course of sentient nature is dictated by malevolence quite untenable. A vast multitude of pleasures, and these among the purest and the best, are superfluities, bits of good which are to all appearances unnecessary as inducements to live, and are, so to speak, thrown into the bargain of life. To those who experience them, few delights can be more entrancing than such as are afforded by natural beauty, or by the arts, and especially by music; but they are products of, rather than factors in, evolution, and it is probable that they are known, in any considerable degree, to but a very small proportion of mankind. (164)

For Huxley, human aesthetic sensibilities, a random by-product of evolution serving no function in the struggle for survival, are nevertheless wonderful "superfluities”, the pleasures of which might offer consolation for nature's moral indifference. Huxley was sure that "artists are born, not made": these developed aesthetic gifts were given only to the few (“Struggle” 173). Wilde’s reflection on the relationship between art and nature in "The Decay of Lying” becomes, in this context, more than a protest against realism; like Huxley, Vivian also suggests that aesthetic gifts afforded to a minority allow individuals to distinguish themselves from the rest of animal life, and provide them with compensation for nature's lack of purpose. As he proclaims: 
My own experience is that the more we study art, the less we care for nature. What art reveals to us is nature's lack of design, her curious crudities, her extraordinary monotony, her absolutely unfinished condition [....] Art is our spirited protest, our gallant attempt to teach Nature her proper place. (35)

In “The Decay of Lying”, it is aesthetic man, not Huxley’s ethical man, who becomes a symbol of human progress, distinguished from "the primitive savage, or man as a mere member of the animal kingdom”. While Vivian is sure that “All bad art comes from returning to life and nature, and elevating them into ideals” (55), the nature imagined, as George Levine has also noted, is a distinctly post-Darwinian one, whose driving mechanism has no regard for human values. ${ }^{6}$

In “The True Function”, Wilde argued that Darwin, along with Ernest Renan, made the nineteenth century “a turning point in history": failure "to recognise this is to miss the meaning of one of the most important eras in the progress of the world” (459). Although Wilde is known to have owned On the Origin of Species and The Descent of Man, it is evolutionary arguments mediated via writers such as W. K. Clifford, Huxley and Spencer figures who were also high-profile debaters in the Nineteenth Century - that are cited directly in his Oxford notebook and commonplace book, rather than Darwin himself. ${ }^{7}$ Nevertheless, Darwin performs a symbolic function in the essays: while in "The True Function” he is presented as the supreme example of "sweet reasonableness" and is credited with "the philosophic temper” (458), in “The Soul of Man” Darwin emerges as the consummate individual: one of the few who has managed "to keep himself out of reach of the clamorous claims of others $[\ldots]$ and so to realise the perfection of what was in him [...] to the incomparable and lasting gain of the whole world” (292).

The great artist or scientist, however, did not rise above nature completely: for Wilde's understanding of the development of the mental and aesthetic faculties was shaped 
by strong assumptions about biological inheritance. Wilde's construction of Darwin as one of the rare men of exceptional talent who was born not made has echoes of Huxley’s own

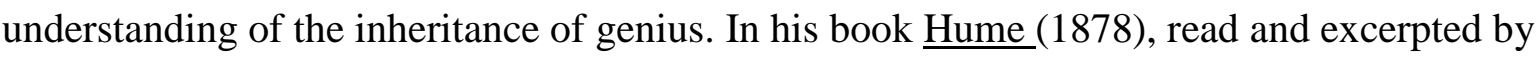
Wilde in his Oxford notebook, Huxley had justified scientific and artistic genius as a type of instinct:

The child who is impelled to draw as soon as it can hold a pencil; the Mozart who breaks out into music as early [...;] the boy Pascal who evolved Euclid out of his own consciousness [...] may be said to have been impelled by instinct, as much as the beaver and the bee. And the man of genius is distinct in kind from the man of cleverness, by reason of the working within him of strong innate tendencies - which cultivation can improve, but which it can no more create, than horticulture can make thistles bear figs. (113)

Wilde's claim, that Darwin realised "the perfection that was in him”, suggests that he indeed developed these “strong innate tendencies”. Although, as Philip E. Smith and Michael S. Helfand have shown, Wilde was well-acquainted with Ruskin's notion of racially inherited aesthetic capabilities (Oxford Notebooks 12), he also placed a significant emphasis on individual genius - on those who deviated from supposed racial norms - as a driving force for artistic development. In “The True Function”, Ernest suggests, “surely you would admit that the great poems of the early world, the primitive, anonymous, collective poems, were the result of the imagination of races, rather than of the imagination of individuals?” Gilbert replies, "Not when they became poetry. [...] Indeed, I am inclined to think that each myth and legend that seems to us to spring out of the wonder, or terror, or fancy of tribe and nation, was in its origin the invention of one single mind” (135).

The philologist Max Müller’s theorisation of the communal creation of myth (as the product of a creative linguistic impulse that arose amongst Indo-European ancestors) was 
well known in the period. It was certainly known by Wilde, who was taught by Müller at Oxford. ${ }^{8}$ Gilbert, however, who takes the dominant role in the dialogue, links creativity to individual genius from humanity’s inception. These capacities are clearly distributed unequally amongst individuals, but the fact that they are evolutionary attributes is not questioned. In “The True Function”, Gilbert maintains:

Temperament is the primary requisite for the critic - a temperament exquisitely susceptible to beauty [...]. Under what conditions, and by what means, this temperament first appeared in the evolution of the race, we will not discuss at present. It is significant to note that it exists, and that there is in us a beauty-sense, separate from the other senses and above them, separate from the reason and of nobler import, separate from the soul and of equal value [...]. But to be purified and made perfect, this sense requires some form of exquisite environment (450).

Like Huxley, Gilbert suggests that while cultivation can perfect this innate tendency, it cannot implant it. Gilbert notes that at first “it is to exist purely as cultivated instinct” (450).

\section{Art and the Evolution of Sympathy}

Huxley and Wilde were not the only writers in the Nineteenth Century to discuss the evolution of complex human attributes assumed to be “impelled by instinct”. Wilde, as a number of critics have noted, revealed obvious debts to Herbert Spencer: notably in his understanding of biological and social evolution as a process of differentiation and specialisation, a movement from homogeneity to increasing heterogeneity. ${ }^{9}$ However, while Wilde’s Oxford notebooks contain quotations from Spencer’s First Principles and Principles of Sociology (28-29), the possible influence of Spencer's later articles for the Nineteenth Century and their links to his works on evolutionary ethics and aesthetics have not been examined. In fact, despite Wilde’s early enthusiasm for Spencer, Vivian makes a somewhat 
slighting reference to him in “The Decay of Lying”: life, he predicts will follow art, "tired of repeating herself for the benefit of Mr Herbert Spencer, scientific historians, and the compilers of statistics in general” (46). Wilde’s direct reference to Spencer creates a selfconscious dialogue with this prominent Nineteenth-Century contributor: a dialogue about sympathy, morality and art that Wilde would continue in "The True Function" and "The Soul of Man”.

In his articles “On Justice” and “On Justice Concluded” - published in the Nineteenth

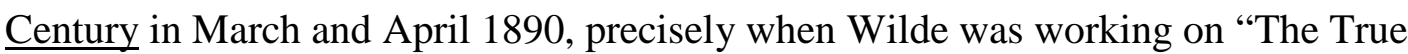
Function” - Spencer argued that the origins of morality lay with a social instinct in animals with survival benefits for the group - an argument that Darwin had previously advanced in the Descent of Man (100-27). ${ }^{10}$ Rather than Huxley's “gladiators' show”, Spencer argued that it was possible to see a primitive form of "animal ethics" in the natural world, including an instinctive sympathy and altruism. The "best” amongst animals were the most adapted, goodness indistinguishable from fitness to evolutionary circumstance ("Justice Concluded” 610). For Spencer, human morality emerged gradually from the struggle for survival, not from conscious attempts to check that struggle.

In "Justice Concluded”, Spencer explicitly directed the periodical's readers to the second edition of his own Principles of Psychology, where he had also discussed the evolution of sympathy and altruism (612). ${ }^{11}$ Those who followed Spencer's lead would have discovered that the Principles of Psychology also devoted considerable attention to the evolution of the "aesthetic sentiments", and argued that the same evolutionary and adaptive process was at work in the production and reception of art. Arguing for a progressive widening of the sympathetic powers as humans became more adapted to society, Spencer asserted that when: 
A long discipline of social life, decreasingly predatory and increasingly peaceful, has allowed the sympathies and resulting altruistic sentiments to develop, these, too, begin to demand spheres of superfluous activity. Fine Art of all kinds takes forms more and more in harmony with these sentiments. Especially in the literature of imagination we may now see how much less appeal there is to the egoistic [...] sentiments, and how much more to the altruistic sentiments - a trait likely to go on growing. (Principles of Psychology 714)

“Aesthetic activities in general may be expected to play an increasing part in human life as evolution advances”, Spencer argued, and they “will in a greater degree than now appeal to the higher emotions” (714). ${ }^{12}$ Suggesting, like Huxley, that art is a by-product of evolution a "play-impulse" (694) that exercises excess human energies, rather than a factor in the struggle for existence - it nevertheless appears to be a gauge of evolutionary progress. For Spencer, art was directly linked to sympathy: indeed, it could only be perfected when humans had become highly adapted to their environment, which would allow their sympathetic instincts to flourish.

Spencer was sure that a "large volume of emotion without painful intensity in any part, is the effect which a successful drama, or poem, or novel, produces", a "variety such as leaves behind no satiety or exhaustion” (709). These emotions, although appealing to moral sentiments, were not a prompt to moral actions: “These are no longer links in the chain of states which prompt and guide conduct” (Principles of Psychology 713). When Gilbert in "The True Function" states that "emotion for the sake of emotion is the aim of art, and emotion for the sake of action is the aim of life, and of that practical organisation of life we call society”, he might be seen to echo a Spencerian understanding of an art whose emotional pleasures are divorced from direct moral consequences, as much as proclaiming discipleship of Pater and the philosophy of art for art's sake (440; italics in original). ${ }^{13}$ 
However, if Wilde, like Spencer, emphasised the evolution of an aesthetic instinct that was not a direct prompt to moral action, he also revealed a clear point of departure from Spencer by arguing against art's appeal to our sympathies. In “The Decay of Lying”, Vivian claims that as "long as a thing is useful or necessary to us [...] or appeals strongly to our sympathies, or is a vital part of the environment in which we live, it is outside the proper sphere of art” (41). Spencer had offered an assessment of the history of art based on the evolution of sympathetic feeling: from the "inferior sentiments" that characterise Greek art, to works of modern art which reveal a still imperfect stage of social evolution, that are "low" in the "sensual and the sanguinary" emotions they "express and arouse" (Principles of Psychology 712). Wilde did something more radical: he sought to sever familiar links between aesthetic taste and sympathy, and in so doing to question affiliations between taste and a moral sense. These affiliations - familiar to Wilde from both Plato and an eighteenthcentury tradition of moral philosophy - had received a new endorsement by evolutionists such as Spencer and Huxley, but as the product of biological inheritance rather than a Godgiven order.

In his 1877 “Modern 'Symposium”” article for the Nineteenth Century, Huxley had discriminated between social morality - based purely on utility, or "the increase of general happiness" to society - and personal morality. The former was relative: if murder, theft or adultery could be shown to have no negative effect on the general happiness, they could not be classed as immoralities in social terms. However, Huxley asserted that it did not follow "that they might not be personal immoralities":

I see no reason for doubting that the beauty of holiness and the ugliness of sin are, to a great many minds, no mere metaphors, but feelings as real and as intense as those with which the beauty or ugliness of form or colour fills the artistic mind, and that 
they are as independent of intellectual beliefs, and even of education, as are all the true æsthetic powers and impulses. (537)

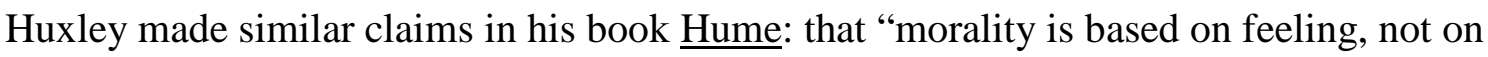
reason” and that "goodness is a kind of beauty" (Hume 207). It was possible, however, to be born without such feelings. As Huxley stated in the Nineteenth Century:

I do not doubt the existence of persons [...] devoid of any sense of moral beauty or ugliness, and for them personal morality has no existence. They may offend, but they cannot sin; they may be sorry for having stolen or murdered, because society punishes them for their social immoralities, but they are incapable of repentance. ("Modern 'Symposium'” 537)

Huxley's hereditary personal morality is a sense of "moral beauty", an "internal taste" that is at the foundation of a moral sense. ${ }^{14}$

In "Pen, Pencil and Poison: A Study", published in the Fortnightly Review in January 1889, Wilde wryly claimed that, despite committing multiple murders, Thomas Griffith Wainwright's "love of art never deserted him”, concluding "there is no essential incongruity between crime and culture. We cannot re-write the whole of history for the purpose of gratifying our moral sense of what should be” (54). For Wilde, here at least, goodness was not a kind of beauty: a beauty sense should not assume a moral sense. Wilde would use The Picture of Dorian Gray, published in its earliest form in Lippincott's Monthly Magazine the same month as “The True Function” appeared in the Nineteenth Century, to question whether heredity could be blamed for individuals whose highly developed aesthetic impulses were not matched by innate moral tendencies. Frequently discussed as both a homage to and a critique of Walter Pater, Dorian Gray, I would suggest, also involves a more subtle engagement with Spencer and Huxley’s assumptions about relationships between inherited ethical and aesthetic faculties. 
Wandering through the ancestral portrait gallery at Selby Royal, Dorian wonders exactly what he has inherited: "had some poisonous germ crept from body to body till it had reached his own?” (Complete Works III: 288). While Dorian claims to be “poisoned” by a book (352), this scene contains its own wry reference to the book that is heavily hinted at: J. K. Huysmans's $\underline{\text { A Rebours. }}{ }^{15}$ Huysman's narrator opens with a tour of his protagonist Des Esseintes’s ancestral portrait gallery, intimating that he is the last of a degenerate biological line. The similarity of these scenes - and the deterministic notion of heredity that they explore - makes the notion that a book can be "fatal", changing biological destiny rather than appealing to innate proclivities, seem dubious. Dorian is devoid of personal morality in Huxley’s terms - the "ugliness of sin” provokes no revulsion in terms of taste and moral feeling: on the contrary, the suffering of others becomes a source of aesthetic pleasure. The narrator muses on the possibility of a biologically determined morality that shakes the very foundations of individual responsibility:

There are moments, psychologists tell us, when the passion for sin, or for what the world calls sin, so dominates a nature, that every fibre of the body, as every cell of the brain, seems to be instinct with fearful impulses. Men and women at such moments lose the freedom of their will. They move to their terrible end as automatons move. (Complete Works III: 330)

The narrative voice is famously slippery. It is materialist science (psychology) rather than the narrator himself that seems to endorse this moral determinism. Yet the notion of a brain and body "instinct with fearful impulses", and an understanding of sin as "passion" points to moments, at least, when moral decisions are not decisions at all, but the workings of a biological destiny impelled by feelings and instincts. 
In his Nineteenth Century articles, Wilde showed a persistent fascination with the idea of morality as an evolutionary and adaptive instinct, founded on emotion rather than reason. In “The True Function”, Gilbert announces:

The security of society lies in custom and unconscious instinct, and the basis of the stability of society, as a healthy organism, is the complete absence of any intelligence amongst its members $[\ldots]$ one is tempted to define man as a rational animal who always loses his temper when he is called upon to act in accordance with the dictates of reason. (446)

Irony aside, Wilde’s language may show traces of his earlier reading of Spencer on the evolution of moral instinct: "what is morality but the perfect adjustment of the human organism to the actual conditions of Life, and to the observance of those inexorable Laws to break which is death”, Wilde wrote paraphrasing Spencer in his Oxford Notebooks (156). ${ }^{16}$ Yet the Notebooks do not tell the full story: there are obvious reasons why Spencer and the claim that social stability is based on "unconscious instinct” would have interested Wilde and his readers at the time of writing. In his second Nineteenth-Century article "Justice Concluded”, published when Wilde was drafting “The True Function”, Spencer had charted the evolutionary progression of morality from an instinctive animal sympathy to a primitive tribal ethics and finally to industrial capitalism's supposedly reflective human altruism. ${ }^{17}$ Spencer argued that "the altruistic sentiment of justice" develops from a more primitive sentiment of justice in which:

four kinds of fear co-operate. The dread of retaliation, the dread of social dislike, the dread of legal punishment, and the dread of divine vengeance, united in various proportions, form a body of feeling which checks the primitive tendency to pursue the objects of desire without regard to the interests of fellow-men. ("On Justice Concluded” 612) 
In Spencer’s formulation, it was not just the “passion for sin”, but also these rudimentary ethical acts - the beginnings of justice towards others - that emerged from (to use Wilde's phraseology) “fearful impulses”. Perhaps there is more than meets the eye to Lord Henry’s assertion in Dorian Gray that "Conscience and cowardice are really the same things" (Complete Works III: 173). Wilde, after all, cautioned in "The Soul of Man” that sympathy with the pain of others includes “a certain element of terror for our own safety” (317). A Spencerian understanding of primitive morality, with its foundations in fear or “dread”, may shape Gilbert’s understanding of “vulgar” ethics: “To be good, according to the vulgar standard of goodness, is obviously quite easy. It merely requires a certain amount of sordid terror, a certain lack of imaginative thought, and a certain low passion for middle-class respectability”. And it also helps to contextualise the striking statement that follows Gilbert's assertion:

Aesthetics are higher than ethics. Even a colour-sense is more important in the development of the individual than a sense of right and wrong. Aesthetics, in fact, are to Ethics, in the sphere of human civilisation, what, in the sphere of the external world, Sexual is to Natural Selection. Ethics, like Natural Selection, make existence possible. Aesthetics, like Sexual Selection, make life lovely and wonderful, fill it with new forms, give it progress, and variety, and change. (“True Function” 458) ${ }^{18}$ Although Wilde clearly employs Darwinian terminology, this passage begs a number of questions. How consistent is Wilde’s science here, and how, exactly, are we to read these metaphors? In a Darwinian schema, aesthetics are not just like sexual selection, but are fundamental to the process, many female animals displaying sophisticated powers of “discrimination and taste” in the selection of males (Descent 246). Wilde’s use of terminology, however - aesthetic capability as a "higher” faculty, which makes life "lovely and wonderful” - suggests a human attribute at once more advanced and less functional in 
evolutionary terms than morality, or at least a Spencerian notion of primitive morality that relies on "sordid terror” to maintain social life.

To claim "Ethics, like natural selection, make existence possible” may also allude to writers who saw them as more than merely analogous - in particular, to scientists who saw natural selection as the evolutionary mechanism that shaped ethical attributes. For Darwin, "social instincts" (including sympathy) that had evolved through natural selection were "the prime principle of man’s moral constitution” (Descent 151). Spencer, while agreeing on the centrality of sympathy, had offered a more strongly Lamarckian account of the evolution of feeling, suggesting that it was possible to inherit “modifications produced by habit”. This mechanism - sometimes known as “use inheritance” - was seen by many nineteenth-century evolutionists to be as plausible as natural selection. In this formulation, social structures, evolving organically over generations, could come to shape instinct and feeling in descendents: “there are further being produced in man,” Spencer argued, “sentiments appropriate to social life” (“Justice Concluded” 609).

Wilde at times seems to endorse both natural selection and inheritance of “modifications produced by habit”, making his conception of the interplay between biology and culture tricky to pin down. ${ }^{19}$ He did not, however, share one of Spencer's key assertions regarding the evolution of feeling: that ongoing moral progress had already been demonstrated by the gradual widening of sympathetic impulses. Wilde's politics in the early 1890s were very different from Spencer’s: Wilde disputed that capitalism was a healthy social structure that fostered "sentiments" conducive to progress. Indeed, Wilde’s distrust of sympathy and altruism in "The True Function" and "The Soul of Man” might be seen as a refutation of a Spencerian position that naturalised capitalism, and claimed it as morally progressive stage of social life. 
While some kind of "moral sense" with a biological origin seems to have been assumed by Wilde, the notion that it could be relied upon alone for ethical decision-making was openly mocked in his writings. In his critical essays, a morality based on feeling alone is often depicted as deeply suspect. While Gilbert in "The True Function" notes that the free market capitalism of the Manchester School appealed to "the lowest instincts", a sentimental “emotional sympathy” is deemed equally dangerous: it is "too variable, too closely connected with the passions” (457). "The real weakness of England [...] lies simply in the fact that her national ideals are emotional and not intellectual", he proclaims (446). His assertion that "it is so easy for people to have sympathy with suffering. It is so difficult for them to have sympathy with thought” (446), is repeated in Wilde's own critical voice in "The Soul of Man” (292).

The striking statement in “A Preface to Dorian Gray”, that "No artist has ethical sympathies” (Fortnightly Review 480) needs to be read, I would argue, not only in the context of the art for art's sake movement, but in light of Wilde’s suspicion of sympathy as an inherently ethical force. ${ }^{20}$ Rather than endorsing Huxley’s notion of “moral sympathies” or Spencer's theorisation of the evolution of altruism, in both "The True Function" and "The Soul of Man”, Wilde argued that the conceptions of sympathy and altruism that had emerged under capitalism had served to maintain an exploitative the status quo. ${ }^{21}$ When Lord Henry announces in Dorian Gray that “The nineteenth century has gone bankrupt through an overexpenditure of sympathy”, this statement functions as more than simple provocation (203). ${ }^{22}$

\section{Art, Tribal Ethics and Sympathetic Individualism}

While Gilbert in the "True Function" is sure that "in the eyes of the thinker, the real harm that emotional sympathy does is that it limits knowledge, and so prevents us from solving any single social problem” (444), in “The Soul of Man” Wilde asserted: “The proper 
aim is to try and reconstruct society on such a basis that poverty will be impossible. And the altruistic virtues have really prevented the carrying out of this aim” (292; italics in original). ${ }^{23}$ Countering Spencer's understanding of sympathy as an inherently moral attribute, he announced:

Sympathy with pain there will, of course, always be. It is one of the first instincts of man. The animals which are individual, the higher animals, that is to say, share it with us. But it must be remembered that while sympathy with joy intensifies the sum of joy in the world, sympathy with pain does not really diminish the amount of pain. It may make man better able to endure evil, but the evil remains. (317) This is a typically Wildean (and possibly wilful) misreading of Darwin: in the Descent it is the gregarious and cooperative animals that are capable of experiencing sympathy and complex social emotions, rather than “animals which are individual” (Descent 100-27). Yet Wilde's wider point is to question whether the feeling of sympathy under capitalism can be an intrinsically moral force: and indeed to question an altruism that substitutes individual self-sacrifice for structural change. Rather than Spencer's understanding of altruistic justice as the product of the most advanced social structure, for Wilde it is a primitive impulse, "merely a survival of savage mutilation” (“The Soul of Man” 315). To live for others (to use the definition of altruism coined by Auguste Comte), is to live for the maintenance of a still rudimentary social state. “It takes a thoroughly selfish age, like our own, to deify selfsacrifice”, asserts Gilbert. "It takes a thoroughly grasping age, such as that in which we live, to set above the intellectual virtues those virtues that are of immediate practical benefit to itself” (“The True Function” 445).

The notion of capitalism as productive of unhealthy emotion "of immediate practical benefit to itself” was outlined clearly in "The Soul of Man”: 
Jealousy, which is an extraordinary source of crime in modern life, is an emotion closely bound up with our conceptions of property, and under Socialism and Individualism will die out. It is remarkable that in communistic tribes jealousy is entirely unknown. (302)

The Russian anarchist Peter Kropotkin, openly admired by Wilde, was also a regular presence in the Nineteenth Century while "The Soul of Man" was in gestation; indeed one of Kropotkin’s articles, “Mutual Aid Among Animals”, was published in the same monthly issue as the second part of Wilde’s “The True Function”. ${ }^{24}$ Significantly, Kropotkin’s series on mutual aid was initially conceived as a rebuttal of articles by Huxley in the Nineteenth Century: Kropotkin sought to counter Huxley’s assumptions concerning nature’s “gladiators' show” in "The Struggle for Existence”, as well as his endorsement of private property in "On the Natural Inequality of Men” (Jan. 1890) and “Natural and Political Rights” (Feb. 1890).

In "Natural Inequality", Huxley had maintained that the patriarchal family was the earliest form of society, and that "almost all parts of the world, and almost all nations, have yielded evidence that, in the earliest settled condition we can get at, land was held as private or several property, and not as the property of the public, or general body of the nation” (17). Kropotkin contested this developmental narrative: tribes practising communal ownership, not families, were the first social units, he asserted in “Mutual Aid Among Savages” (Apr. 1890). "Far from being a primitive form of organization", he announced, "the family is a very late product of human evolution” (540). Kropotkin’s attempts to counter Huxley’s assertions which included mounting the case for the "primitive communism" of tribal societies - echo Wilde’s own comments on the “communistic tribes” in which "jealousy is entirely unknown”. Kropotkin drew on Darwinian theorisations of cooperative instincts and anthropological accounts of tribal morality to justify a political evolutionary narrative that 
was very different from Huxley’s, predicting an inevitable progression towards a communitarian permutation of anarchism.

Moreover, Kropotkin was not the only writer in the Nineteenth Century to use evolutionary theory to question Huxley and Spencer’s naturalisation of capitalism. In “A Working Man’s Reply to Professor Huxley”, J. D. Christie, who described himself as a pastry cook, used a Spencerian vocabulary to overturn Spencerian and Huxleyian conclusions about the dangers of socialism. The misery of social inequality, Christie argued, must be dealt with, for "its existence demonstrates some maladjustment in the social organism” (477). The permanence of capitalism was to be challenged on the same evolutionary principle that led Spencer to question the permanence of human nature. While Spencer had pointed to the error of those who "will not accept the adjustability of human nature to social life" ("Justice Concluded” 609), Christie had also argued for human adjustability - but an adjustment that would be linked to socialism as the most progressive form of social development.

While socialist and anarchist theorisations of evolutionary morality published in the Nineteenth Century play a notable role in shaping Wilde's critique of altruism in "The Soul of Man”, Darwinian-inflected understandings of tribal morality were also part of Wilde’s formative reading, as his extensive paraphrases from W. K. Clifford in his Oxford commonplace book attest. Wilde owned Clifford's Lectures and Essays, and was particularly interested in Clifford's “On the Scientific Basis of Morals”, first published in the Contemporary Review under James Knowles (1875). Clifford's article was inspired by Darwin's reflections on the significance of co-operative instincts in ensuring group survival in the Descent of Man. Under the heading of "Moral Chemistry" in his commonplace book, Wilde paraphrased Clifford: "the force of categorical imperative of the modern moral sense rests on the fact that natural selection has left to survive only those tribes in whom a tribal 
sense is strong and also by the strong punishments inflicted on any violation of tribal rules" (Oxford Notebooks 130).

While Smith and Helfand have claimed that Wilde believed "humane qualities did not evolve through natural selection” (Oxford Notebooks 84), this assertion may need to be revised in light of both Wilde's early engagement with Clifford and his subsequent participation in Nineteenth Century debates. Indeed, Wilde's departure from an idealist position on the subject of the evolution of the human faculties - including the "humane qualities" - is brought into sharper relief when his assertions in "The True Function” are compared with other articles published in the Nineteenth Century, such as H. Carlisle's “Wallace on Darwinism”, which appeared in the periodical four months before the first part of Wilde’s “The True Function” was published.

Reviewing Alfred Russell Wallace’s widely discussed book Darwinism, Carlisle echoed Wallace's own criticism of “the application of the principle of natural selection to the evolution of the human faculties” (412). Carlisle cited Wallace's claim that Darwin's “whole argument tends to the conclusion that man's entire nature and all his faculties, whether moral, intellectual, or spiritual, have been derived from their rudiments in the lower animals, in the same manner and by the action of the same laws as his physical structure has been derived", materialist claims that both Wallace and Carlisle both sought to refute (412). ${ }^{25}$ Gilbert's assertion that there is no form of human emotion that is not shared with the lower animals takes on new significance in the light of these controversies. Readers who turned to Kropotkin’s “Mutual Aid among Animals” after finishing the concluding part of Wilde’s "The True Function” would have found a continuation of this debate about the evolution of morality. Kropotkin maintained that "very often self-sacrifice for the common welfare" was the rule in animal as well as human communities (334); Darwinian natural selection for cooperative qualities did indeed, he argued, explain “moral development” (337). 
Wilde’s “Soul of Man” offers a similarly politicised reading of the evolution of cooperation: both Kropotkin and Wilde use the ethics of "communistic tribes" to refute the naturalisation of capitalist individualism. Wilde’s commonplace book, however, reveals that, in his earlier engagement with Clifford, a nascent interest in the relationship between ethics and private property is already apparent. Noting that the "basis of our moral Feelings may be found in the desire for self-preservation”, Wilde was careful to clarify that:

This preservation of self is not the individual self but what Clifford calls the "Tribal Self”: individualism, private property, and a private conscience [...] do not appear till late in all civilizations: it is the Tribal self wh. is the first mainspring of action, and canon of right and wrong: a savage is not only hurt when a man treads on his own foot, but when the foot of the tribe is trodden on. (Oxford Notebooks $129-30)^{26}$ Private property, Wilde suggests, is not foundational to early society, nor is it fundamental to human nature - a claim that is not directly discussed in Clifford's essay, but which set Wilde at odds with both Huxley and Spencer. In “[The Rise] of Historical Criticism”, Wilde had made clear that he believed the family - linked explicitly by Henry Maine, and later, Huxley, to the first societies and to property acquisition - was instead a late arrival in civilisation (Complete Works IV: 22-26). "Neither in its matured development, or in its earliest starting point of evolution, is the canon of ethics the greatest happiness of the greatest number but the preservation of the Tribe, its highest excellence”, Wilde had paraphrased from Clifford’s essay in his commonplace book, emphasising the significance of the tribal self to future social development. He went on to add, significantly, "nor is goodness merely altruism, or service to others because they are others, but service done to a community by an individual who is part of that community”, drawing on Clifford's own distinction between piety and altruism (Oxford Notebooks 130). ${ }^{27}$ 
If the periodicals in which Wilde published were known for their fearless explorations of evolution and ethics - for their willingness to consider biological and secular as well as religious explanations for morality - Wilde’s own early interest in this subject was also shaped by his engagement with the writings of those agnostics in James Knowles's periodical circles. The trenchant attack on religion in Clifford's 1877 Contemporary Review article "The Ethics of Belief” was partly responsible for the existence of the Nineteenth Century - it was the catalyst for the removal of Knowles as editor of the Contemporary, and for his foundation of the new periodical. Along with Huxley, Clifford was a contributor to the Nineteenth Century’s 1877 “Modern 'Symposium’” debate “The Influence upon Morality of a Decline in Religious Belief", where he had also suggested that "the spring of virtuous action is the social instinct”, claiming the conscience was an inherited race instinct, the product of a “wider self” (956-57).

It is notable that debates over property in the Nineteenth Century in the early 1890s were often linked to wider disputes about the evolution of moral impulses - including those provoked by Spencer’s “On Justice” and Huxley’s “On the Natural Inequality of Men”. Spencer asserted in "On Justice” that the love of property was instinctive in both animals and humans, and was a feeling that decisively shaped the growth of both early and modern social structures. In "The Soul of Man”, Wilde disputed that property was a source of instinctive pleasure.

Private property has crushed true Individualism, and set up an Individualism that is false. It has debarred one part of the community from being individual by starving them. It has debarred the other part of the community from being individual by putting them on the wrong road, and encumbering them. [...] One's regret is that society should be constructed on such a basis that man has been forced into a groove 
in which he cannot freely develop what is wonderful, and fascinating, and delightful in him - in which, in fact, he misses the true pleasure and joy of living. (296-97) The question of how society can be both a "construct” and an evolutionary state is never answered in “The Soul of Man” - surely a problem for the essay’s coherence. However, Wilde's commitment to a model of progressive organic social evolution (albeit one which fails to explain how capitalism as a digression down the "wrong road" emerges) may also help to explain the need to redefine individual freedom in the essay. What is clear is that in Wilde’s schema, aesthetic pleasure - possible only for the unfettered individual whose gifts are allowed to develop without social impediment - is the true symbol of the "joy of living". Wilde's conception of an individualism that can be reached only through socialism overturns Spencer and Huxley's understanding of both concepts. ${ }^{28}$ Yet Wilde explicitly draws on Spencerian phraseology - arguing that Socialism will "restore society to its proper condition of a thoroughly healthy organism” - to refute Spencer’s political conclusions. ${ }^{29}$

Given Wilde uses “The Soul of Man” to challenge assumptions about “morbid” art and to champion artistic individualism, his simultaneous endorsement of the link between art and social health is striking. In the socialist future, a new understanding of individualism will lead to a reconfigured sympathy: it will "be large, healthy, and spontaneous”. Sympathy with pain is "tainted with egotism” and "apt to become morbid". ${ }^{30}$ Under socialism individuals will sympathise with "life’s joy and beauty and energy and health and freedom” (“The Soul of Man” 317). “The evolution of man is slow”, claimed Wilde in this article (318), but it was assumed nevertheless, as a progression that would allow society to develop beyond capitalism and its "unhealthy" altruism. And while Wilde sought to wrest sympathy from its Spencerian definition, once a "true" definition had been substituted, the relationship between its gradual widening and social progress could be restored. Wilde’s decadent aesthetic, here at least, is combined with a distinct endorsement of social meliorism. This is why art in "The 
Soul of Man” can take such a paradoxical role, standing simultaneously as a symbol of individualism and of the moral state of the nation.

Appreciation of Wilde’s engagement with wider periodical literature might provide deeper insights into his evolutionary meliorism - and indeed his tendencies towards political materialism. Echoing William Morris in News from Nowhere, Wilde asserted in "The Soul of Man" that "the conditions will be done away with, and human nature will change. [...] The systems that fail are those that rely on the permanency of human nature, and not on its growth and development” (315). ${ }^{31}$ In the early 1890s, Morris, whose work Wilde claimed "he would always love” (Letters 290-91), also endorsed a politicised form of ethical evolution that predicted a partial return to tribal morality. The possible influence of not just Morris, but wider Commonweal contributors on "The Soul of Man”'s endorsement of moral evolution should not be overlooked. ${ }^{32}$

Bruce Haley has argued that "Wilde himself [...] regarded his personal and literary styles as models of growth, not degeneracy", a position, he claims, that "he formulated before he was well known” and that owed more to Spencer and Comte than to Pater (215-16). While a model of growth is certainly implied in “The Soul of Man”, Wilde’s position was still evolving in the 1890s, emerging as part of a dialogue on morality, aesthetics and socialism that animated the periodicals in which he was writing. In that dialogue, Wilde sought to challenge Spencer and Huxley’s endorsement of capitalism, even as he adopted their organic analogies.

Pursuing this relationship might offer a more nuanced perspective on Wilde’s attempts to separate art and morality, revealing this manoeuvre to be more than a decadent rejection of didactic art. Wilde, indebted to Huxley's understanding of a directionless nature, also parted company from him in significant ways, including in his suspicion of the moral role that Huxley accorded to feeling. Wilde's scepticism about art's appeal to our sympathies 
needs to be re-read in the context of writings by contemporaries such as Spencer and Huxley, who saw aesthetic and moral faculties as closely intertwined. Well-read in the scientific debates of his day, Wilde came to his own conclusions about sympathy and its dangers. Paradox and wilful contradiction aside, Wilde asserted at least one consistent moral position: while a beauty sense and a moral sense were both conceived as part of our evolutionary heritage, emotion alone should form the foundation of neither ethics nor art.

Smith and Helfand view Wilde’s Oxford notebooks as the intellectual key to his later articles: Wilde is seen as displaying a "carefully reasoned philosophical and political stance”, a synthesis of idealist and Spencerian evolutionary theory that is convincingly adopted from the late 1870s onwards (Oxford Notebooks vii). In contrast, Guy's Wilde is a very different creature, a journalist whose periodical writings are far from intellectually coherent: they are, she argues, self-consciously topical and provocative pieces that reveal philosophical and political contradictions (Guy, “'Soul of Man’”). This article has made the case that, while the Oxford Notebooks establish Wilde’s long-standing engagements with evolutionary debates, the periodical contexts of the 1890s play an important role in shaping his literary use of this theory. In the pages of the Nineteenth Century and Fortnightly Review, Wilde's literary dialogues were intentionally open-ended, creating their meanings as part of a wider journalistic conversation. Wilde’s provocative style spoke to readers used to pondering the big questions: not only the place of aesthetics and ethics, but the nature of their own evolution as moral and art-loving animals.

\section{NOTES}

\footnotetext{
1 “The True Function" was revised for Intentions as "The Critic as Artist”, the title by which it is now better known.

${ }^{2}$ See Guy, "The Soul of Man” in Wilde Writings 59-85 and introduction to Wilde, Complete Works IV: lxxvi-lxxi.

${ }^{3}$ The Fortnightly Review and Nineteenth Century in the 1890s used a number of the same contributors (Huxley and Peter Kropotkin amongst them). The Metaphysical Society (1869-80),
} 
presided over by the Nineteenth Century's editor James Knowles, included agnostics and atheist thinkers with clear interests in science and ethics who became important contributors to the periodical (including W. K. Clifford and Leslie Stephen). On the editorial policies of the Nineteenth Century and the Fortnightly, see Small.

${ }^{4}$ Guy argues that Wilde's reference to "the Church" in the opening of the periodical version of "The Soul of Man" is "almost certainly an allusion to Cardinal Manning, one of the authors of a series of articles on philanthropy entitled 'Irresponsible Wealth' which appeared in the Nineteenth Century in Dec. 1890,” two months before the publication of Wilde’s article’ (in Wilde, Complete Works IV: lxxvi-lxxi). Guy also notes Wilde's praise of the Nineteenth Century, despite disagreeing with Knowles's editorial decision to split "The True Function" into two articles.

${ }^{5}$ Wilde claimed that "The Decay of Lying" was sketched out at a dinner with Robert Ross, a meeting Guy has suggested is unlikely to have taken place before late November or early December 1888; this timing means Huxley's "Struggle" could easily be a direct influence. It should be noted, however, that the influence was not mutual: Huxley was no appreciator of Wilde in person or enthusiast for aestheticism in literature (see Dawson 190-221).

${ }^{6}$ Levine has also argued for art's consolatory power for Wilde in a post-Darwinian context in "The Decay of Lying"; while I broadly agree with this analysis I argue that it is Huxley, rather than Darwin, who is the most obvious direct influence on Wilde's formulation of aesthetics.

${ }^{7}$ On Wilde's library, which also included Spencer's First Principles, see Wainwright 496.

${ }^{8}$ On Müller's influence see Smith and Helfand, Oxford Notebooks 204.

${ }^{9}$ On this aspect of Spencer's influence on Wilde see Haley and Smith and Helfand, Oxford Notebooks 29.

${ }^{10}$ Darwin placed a much stronger emphasis on natural selection as the mechanism that developed these traits than Spencer, although he also drew attention to the role of reason, habit and culture. Spencer's articles "On Justice” would later form part of his Principles of Ethics (1892-93).

${ }^{11}$ This edition was first issued in parts from 1872-3. The material on altruism and aesthetics was absent from the first edition (1855).

${ }^{12}$ See also Spencer's article on "The Origin and Function of Music" (first published in Fraser's Magazine in 1857), in which he discusses music as a language of feeling which promotes sympathetic communication, and predicts a future in which "feelings of higher and more cultivated kinds, as yet experienced only by the cultivated few, will become general” (Literary Style and Music 75).

${ }^{13}$ Cohen has rightly drawn attention to the similarity of Wilde's phraseology to Pater's essay on Wordsworth, where "sterility" is also assumed in the contemplation of art (110-11). While I do not dispute this influence, Pater's claim that "the end of life is not action but contemplation" is also different from Wilde's separation of the role of emotion in life and art in this passage.

${ }^{14}$ In his book Hume, Huxley approvingly cited Hume's claim that for virtue to be "desirable on its own account $[\ldots]$ merely for the immediate satisfaction which it conveys, it is requisite that there should be some sentiment which it touches; some internal taste or feeling [...] which distinguishes moral good and evil, and which embraces one and rejects the other" (206-7).

${ }^{15}$ For an interesting discussion of heredity in Wilde that also touches on Huysman, see Foster, "Against Nature? Science and Oscar Wilde" in Between Shadows 38-43. Wainwright also focuses on heredity in Dorian Gray, with a particular focus on August Weissmann; I, however, would dispute his claim that Wilde "enjoyed the comfort of religion reconciled to the natural mechanism of evolution" (510).

${ }^{16}$ As Smith and Helfand suggest, this claim echoes Spencer's Data of Ethics (Oxford Notebooks 205).

${ }^{17}$ Spencer noted in The Principles of Psychology, "I gladly adopt this word, for which we are indebted to M. Comte” (673).

${ }^{18}$ Critics have struggled to make sense of this Darwinian analogy. Smith and Helfand have interpreted it as evidence that Wilde formulated a "nonauthoritiarian socialist theory" that encouraged "reduced competition (and thus natural selection) as the way of achieving continuous cultural and social improvement” (Oxford Notebooks 206). Given natural and sexual selection are both competitive mechanisms, however, this reading seems hard to justify.

${ }^{19}$ See, for instance, the considerable ambiguity in Wilde's phraseology when he discusses Plato's recommendations for the development of aesthetic temperament in "The True Function": "By slow 
degrees there is to be engendered in [the young Greek] such a temperament as will lead him naturally and simply to choose the good in preference to the bad, and rejecting what is vulgar and discordant, to follow by fine instinctive taste all that possesses grace and charm and loveliness". Temperament is both "engendered" and becomes instinctive, suggesting a Lamarckian notion of the inheritance of acquired characteristics (450).

${ }^{20}$ Wilde made this claim eight months earlier in a letter "To the Editor of the Scots Observer"; see Bristow in Wilde Complete Works III: lvii.

${ }^{21}$ For a more detailed account of Darwinian, Huxleyan and Spencerian formulations of sympathy, see Sumpter, "On Suffering”.

${ }^{22}$ Lord Henry's reflections on sympathy appear only in the 1891 version of Dorian Gray, and are closely linked to Wilde's subsequent assertions in "The Soul of Man”.

${ }^{23}$ As Dixon notes, Wilde also rejects the designation of Christ as altruist in De Profundis (Invention of Altruism 340-43). For suggestive studies of the pervasiveness of altruism as a concept in this period, see Collini (60-90) and Dixon.

${ }^{24}$ On Wilde's references to Kropotkin see Wilde Complete Works II: 184-85.

${ }^{25}$ Wallace did acknowledge that this was not a direct statement from Darwin; in fact, the Descent is much more balanced in its discussion of culture and habit as well as biological instinct as forces that shape morality.

${ }^{26}$ Clifford claimed, "We must carefully distinguish the tribal self from society, or from 'the common consciousness'; it is something in the mind of each individual man which binds together his

gregarious instincts." However, the tribal self is not associated specifically with primitivism: "The word tribe is here used to mean a group of that size which in the circumstances considered is selected for survival or destruction as a group” (Lectures and Essays 112; italics in original).

${ }^{27}$ Clifford preceded the claims about community paraphrased by Wilde with the assertion "Piety is not Altruism", using the former to refer to the communal ethic of the tribal self. Clifford's formulation that the individual "loses in that service the consciousness that he is anything different from the community" is stronger than Wilde's (Clifford Lectures and Essays 122).

${ }^{28}$ For a broader contextualisation of debates over individualism that may have shaped "The Soul of Man”, including the role of Spencer, see Guy "'Soul of Man”' 72-78, and Thomas.

${ }^{29}$ This terminology is also found in Clifford's "On the Scientific Basis of Morals”, where he suggests that "the social organism, like the individual, may be healthy or diseased". He adds: "certain social diseases consist in a wrong direction of the conscience" (Lectures and Essays 122).

${ }^{30}$ This is a close paraphrase of Lord Henry's pronouncement in Dorian Gray (Complete Works III: 203).

${ }^{31}$ Lamarckian tendencies in both Wilde and Morris's thought may help to explain how sympathy can be perceived as both instinctive and an instinct seemingly perverted by capitalism. Although Wilde refers to "My friends the Fabianists" in "The Soul of Man", the notion that true socialism involves the disbanding of the state has more in common with Morris than with Fabian socialism.

${ }^{32}$ On the many articles on tribal morality published in the Commonweal (including direct responses to Huxley's Nineteenth Century articles), see Sumpter, "Anthropology”. Thomas has argued that News from Nowhere's serialisation in the Commonweal between January and October 1890 means it "was almost certain to have been ready to the hand and thought of Oscar Wilde while he was preparing 'The Soul of Man Under Socialism'” (86). If, as Guy has asserted, “The Soul of Man” was substantially written in late autumn and early winter of 1890, this direct influence seems plausible (Wilde Complete Works IV: ixx). Both Kropotkin and Morris believed that the aggression towards outsiders that characterized tribal society would be lessened in a politically progressive society that conceived community in much wider terms, which has interesting parallels with Wilde's own notion of cosmopolitanism.

\section{WORKS CITED}


Clifford, W. K. Lectures and Essays. Ed. Leslie Stephen and Frederick Pollock. Vol 2. London: Macmillan, 1879.

__ “. A Modern 'Symposium': Influence upon Morality of a Decline in Religious Belief”. Nineteenth Century 1 (1877): 353-58.

Carlisle, H. “Wallace on Darwinism”. Nineteenth Century 27 (1890): 408-23.

Cohen, Philip K. The Moral Vision of Oscar Wilde. London: Associated UP, 1978.

Collini, Stefan. Public Moralists: Political Thought and Intellectual Life in Britain 18501930. Oxford: Oxford UP, 1991.

Christie, J. D. “A Working Man’s Reply to Professor Huxley”. Nineteenth Century 27 (1890): 476-83.

Darwin, Charles. The Descent of Man, and Selection in Relation to Sex. London: Penguin, 2004.

Dawson, Gowan. Darwin, Literature and Victorian Respectability. Cambridge: Cambridge UP, 2007.

Dixon, Thomas. The Invention of Altruism. Making Moral Meanings in Victorian Britain. Oxford: Oxford UP, 2008.

Foster, John Wilson. Between Shadows: Modern Irish Writing and Culture. Dublin: Irish Academic Press, 2009.

Guy, Josephine. M. “'The Soul of Man Under Socialism’: A (Con) Textual History”. Wilde Writings: Contextual Conditions. Ed. Joseph Bristow. Toronto: U of Toronto P, 2003): 59-85.

Haley, Bruce. “Wilde’s 'Decadence’ and the Positivist Tradition”. Victorian Studies 28.2 (1985): 215-229

Huxley, T. H. Evolution and Ethics. London: Pilot, 1947.

—. Hume. London: Macmillan, 1879.

—_. "A Modern 'Symposium'”: The Influence upon Morality of a Decline in Religious Belief”. Nineteenth Century 1 (1877): 536- 39.

—_. “On the Natural Inequality of Men”. Nineteenth Century 27 (1890): 1-23.

—. “The Struggle for Existence: A Programme”. Nineteenth Century 23 (1888): 161-80.

Kropotkin, Peter. “Mutual Aid Among Animals I”. Nineteenth Century 28 (1890): 337-54.

—_. "Mutual Aid Among Savages”. Nineteenth Century 29 (1891): 538-59. 
Levine, George. Darwin the Writer. Oxford: Oxford UP, 2011.

Small, Helen. "Liberal Editing in the Fortnightly Review and the Nineteenth Century". Publishing History 53 (2003): 75-96.

Spencer, Herbert. The Data of Ethics. London: Williams and Norgate, 1879.

—. Literary Style and Music. London: Watts, 1950.

—_. “On Justice’; “On Justice Concluded”. Nineteenth Century 27 (1890): 435-48, 608-20.

—.The Principles of Psychology. $4^{\text {th }}$ ed. Vol 2. London: Williams and Norgate, 1899.

Stephen, Leslie. “Thomas Henry Huxley”. Nineteenth Century 48 (1900): 905-18.

Sumpter, Caroline. “Anthropology, Socialist Prediction and William Morris’s Commonweal.” Cultural and Social History 9.3 (2012): 349-67.

— . "On Suffering and Sympathy: Jude the Obscure, Evolution and Ethics". Victorian Studies 53.4 (2011): 665-87.

Thomas, J. D. “The Soul of Man under Socialism: An Essay in Context”. Rice University Studies 51 (1965): 83-95.

Wainwright, Michael. "Oscar Wilde, the Science of Heredity, and The Picture of Dorian Gray”. ELT 54 (2011): 494-522.

Wilde, Oscar. Complete Letters. Ed. Merlin Holland and Rupert Hart-Davis (London: Fourth Estate, 2000).

—. The Complete Works of Oscar Wilde II: De Profundis 'Epostola: in Carcere et Vinculis'. Ed. Ian Small. Oxford: Oxford UP, 2005.

- The Complete Works of Oscar Wilde III: The Picture of Dorian Gray 1890 and 1891 Texts. Ed Joseph Bristow. Oxford: Oxford UP, 2005.

—. The Complete Works of Oscar Wilde IV: Criticism: Historical Criticism, Intentions, The Soul of Man. Ed. Josephine M. Guy. Oxford: Oxford UP, 2007.

_ “The Decay of Lying: A Dialogue”. Nineteenth Century 25 (1889): 35-56.

- Oscar Wilde's Oxford Notebooks: A Portrait of Mind in the Making. Ed. with a commentary by Philip E. Smith and Michael S. Helfand. Oxford: Oxford UP, 1989.

—_."Pen, Pencil, Poison: A Study”. Fortnightly Review 45 (1889): 41-54.

—_. “A Preface to “Dorian Gray”’. Fortnightly Review 55 (1891): 480-81. 
. “The Soul of Man Under Socialism”. Fortnightly Review 49 (1891): 292-319.

—. "The True Function and Value of Criticism; With Some Remarks on the Importance of Doing Nothing: A Dialogue. Parts I and II”. Nineteenth Century 28 (1890): 123-47, 435-59. 